\title{
AN EVALUATION OF THE VARIABLES AND TERMINOLOGIES EMPLOYED IN THE CONSTRUCTS OF SCM PRACTICES
}

\author{
Eliciane Maria da Silva \\ Methodist University of Piracicaba (UNIMEP) \\ eimsilva@unimep.br \\ Mario Sacomano Neto \\ Methodist University of Piracicaba (UNIMEP) \\ msacomano@unimep.br \\ Sílvio Roberto Ignácio Pires \\ Methodist University of Piracicaba (UNIMEP) \\ sripires@unimep.br
}

\begin{abstract}
The main aim of this study was to conduct a meticulous analysis of which words or terms are used in the variables that best represent the concepts of SCM practices. The research conducted can be classified as being of a descriptive, exploratory and qualitative character. The search of the articles was made in the Scopus and Web of Science. The final sample was composed of 51 articles, drawn from 18 periodicals. For analysis, the definition of a construct was taken as the base, its relation with manifested variables and words or terms most used and coherent with the definition of the concepts and the contexts in which these terms were applied. A total of 639 variables that defined constructs, were transcribed. Similarity is noted in the employment of their variables and common use of words in the definition of the concepts. However, the constructs possess different nomenclatures. Therefore, confusion is present in the studies analyzed. The study sought to contribute to greater discernment of the concepts, making a critical reflective understanding of the practices in the area. It was raised in the subsections of the discussions that the authors used the same terms in different contexts. It was pointed out the future prospects for formation of the concepts, showing how such constructs are being modified and perfected by means of the introduction of theories, such as the theory of Transaction Cost Economics, the Resource-Based View, Agency Theory, and Knowledge-Based Theory.
\end{abstract}

$\varnothing$

$\not$

$\not \quad \phi$

$\not \subset$

\section{INTRODUCTION}

In the last few decades, the literature about Supply Chain Management (SCM) has frequently advocated that the level of integration, upstream and downstream integration, in a supply chain is an important factor in a company's business strategy, as highlighted in Frohlich and Westbrook (2001), Li et al. (2006) and Mackone-Sweet and Lee (2009). Thus, a high level of integration in the supply chain can lead to better performance, which requires joint execution of activities, functions and management throughout the supply chain (Narasimhan \& Jayaram, 1998; Vickery, Jayaram, Droge, \& Calantone, 2003). Various studies have sought to identify the impact of joint practices in the supply chain on operational and business performance (e.g., Bozarth, Warsing, Flynn, \& Flynn, 2009; Flynn, Huo, \& Zhao, 2010; Fynes, Voss, \& Búrca, 2005b; Li et al., 2006; Tan, Kannan, Hsu, \& Leong, 2010). Consequently, there has been an evolution and dissemination of concepts in the area, whose studies use a large number of variables relating to the supply chain and business performance, besides employing different nomenclatures for the definition of similar concepts.

Additionally because SCM is truly a functionspanning discipline, research streams are developing within the journals in several different disciplines (eg. Operations, Marketing, Logistics). The increased research attention, when combined with research streams in several functional areas, is lead- 
ing to an increase in the quantity of terms, concepts, models, and taxonomies used in literature. And because authors in one discipline may not be familiar with the research in other disciplines, confusion and a lack of consistency has developed within our literature. This problem can also exist in practice as well, as different firms within a supply chain may use their own internally and culturally developed terminologies, concepts, and acronyms as they try to increase collaboration within their supply chains. The use of many different terms could be hindering the effective implementation of supply chain practices within a firm and between firms in the supply chain. Therefore, it is important to try and develop taxonomies that can be more widely used by academics and practitioners to advance this area. In this sense, meticulous analysis of terms and constructs makes a relative contribution to this field of study.

At present, there has also arisen some research concerned with creating taxonomies (classifications) of the concepts in the area. However, the number of studies is still relatively limited. For example, Mckone-Sweet and Lee (2009) developed a taxonomy of strategies, involving concepts of organizational capabilities (employing concepts of co-ordination, planning, involvement of suppliers and consumers), and internal capabilities (using information technology), in an empirical study of 212 firms. The taxonomy developed was composed of three levels of implementation of organizational capabilities and information technology. The results revealed that these two practices are complementary, and, when employed jointly, they contribute to improvement in performance, especially in the dimensions of cost, quality, delivery and flexibility. Nevertheless, such study only went into depth on these two themes (organizational capabilities and internal capabilities), analyzing the taxonomy for three implementation levels. Also, they used traditional performance measurements in manufacturing strategy. On the other hand, in the study by Arzu Akyuz and Erman Erkan (2010), a literature review is presented about performance measurements in the supply chain. Such study contributed to the taxonomy of concepts, made a detailed description of the 24 articles selected and brought prospects for future research. These authors classified the articles evaluated into six subgroups with common themes. The discussions dealt with current problems of performance measurement systems, the requirements of adequate metrics, the importance of Balanced Scorecard and the SCOR model, and the importance of alignment in the per- formance measures in the supply chain. Among the conclusions and suggestions for future research, the cited study reinforces that it is evident that there is immaturity in the models and frameworks developed, and that more research effort is necessary in this area.

In turn, Vanpoucke, Boyer and Vereecke (2009) created a taxonomy with three types of information flow strategies among firms, through analysis of 112 strategic alliances among suppliers and consumers linked to a main company. Among the results, it is revealed that the integration of information in strategic alliances is not very advanced, as the firms do not invest in technology to integrate information, and there is no single integrated system. Despite bringing significant contributions to academia and management practice, their study goes deeply into only one Supply Chain Management subject, that is, the integration of information among firms in strategic alliances.

Although there is growth in research, there are evident gaps in the creation of taxonomies of concepts in the Supply Chain Management area, bearing in mind the amplitude of the themes researched in various publications, such as: supplier evolution system (Chow et al., 2008; Dabhilkar, Bengtsson, von Haartman, \& Ahlström, 2009; Narasimhan \& Das, 2001; Narasimhan \& Jayaram, 1998), supplier development support (Carr \& Kaynak, 2007; De Toni \& Nassimbeni, 2000; Sambasivan, Loke, \& AbidinMohamed, 2009), supplier relationships or partnership (Chen, Paulraja, \& Lado, 2004; Narasimhan \& Das, 2001; Sodhi \& Son, 2009), communication methods (Carr \& Kaynak, 2007; S. W. Kim, 2009; Paulraj, Chen, \& Flynn, 2006), customer integration (McKone-Sweet \& Lee, 2009; Narasimhan \& Kim, 2002; Robb, Xie, \& Arthanari, 2008), among others. Consequently, due to the amplitude of the themes, there is also a dearth of research providing greater understanding of the concepts. Such research motivated the development of this study which seeks to answer the following questions:

- Which current practices are most employed in empirical studies of the contemporary Supply Chain Management area? Which variables best define (or represent) the concepts in this area?

In order to answer these questions, the main aim of this study was to conduct, in an exploratory manner, a meticulous analysis of which words (or terms) are used in the variables that best represent the concepts 
of SCM practices. For this, a deep analysis was made of research regarding practices and performance in the supply chain. Matitz and Vizeu (2010) reported that the concepts are mentioned and conveyed in the form of terms, creating a dynamic specialized vocabulary for the area, it being the responsibility of the science to clarify the concepts that are part of the definition of other concepts, seeking integration among different theoretical levels. Furthermore, it is reinforced by the referred authors that these concepts can create communicative problems when the same term is utilized simultaneously by frameworks of distinct references. Besides this, it is necessary to consider the possibility of concept change, as knowledge of this phenomenon is perfected or modified.

The contribution of this work is centered on obtaining a clearer definition of the concepts of Supply Chain Management practices from the studies researched, grouping them into broader, deeper concepts.

This study also contributes to methodological analysis by selecting and evaluating the most used and coherent terms in defining the constructs and subconstructs into of the contexts in which these terms were applied. Although there are various articles that mention SCM practices and performance, no taxonomy has been found of the concepts in the area with analysis similar to that presented in this article.

\section{RESEARCH DESIGN}

The research conducted can be classified as being of a descriptive, exploratory and qualitative character, as it involved the analysis of words (or main terms used in Supply Chain Management) found in the concepts.

The search of the articles was made in the databases, Scopus and Web of Science using the Boolean expression, "Supply Chain Management and Performance", writing these words together and research- ing from 1997 to 2010, since it is the period that practically characterizes the emergence and expansion of the SCM concept in the literature. In the first search, 2,386 articles were found. Such publications were selected for analysis of the content of the summaries, of the validation of the concepts and methodological technique employed.

As regard to the analysis of the content of the summaries, we selected the articles that investigated the effects of the supply chain practices on performance. In sequence, we analyzed the full article and investigated if these articles validated the performance and supply chain practice concepts by statistic techniques, for example Confirmatory or Exploratory Factorial Analysis. Then these validated constructs and its variables were transcribed to an electronic spreadsheet for the data analysis. After the selection of the articles, the final sample was composed of 51 articles, drawn from 18 periodicals (Table 1).

For analysis of the main terms most used in SCM, the definition of a construct was taken as the base, its relation with manifested variables and words or terms most used and coherent with the definition of the concepts.

According to Hair Junior et al. (2005), the construct represents a concept defined in theoretical terms, which, however, cannot be measured directly or perfectly, but must be approximately measured by variables (or indicators). These authors further argue that the constructs of the first order are subdimensions of a broader more general construct, or one of the second order. In a complementary manner, Matitz and Vizeu (2010) define that concepts of a high degree of abstraction are called constructs, as they are constricted from concepts of a lower level of abstraction. Moreover, the cited authors clarify that the concepts are conveyed by means of words (or terms) that confer to them communicative materiality. 
Table 1: Periodicals comprising the sample

\begin{tabular}{|l|c|}
\hline \multicolumn{1}{|c|}{ Periodical } & $\begin{array}{c}\text { Number of } \\
\text { articles }\end{array}$ \\
\hline Benchmarking & 1 \\
\hline Decision Sciences & 2 \\
\hline European Journal of Purchasing \& Supply Management & 1 \\
\hline IEEE Transactions on Engineering Management & 1 \\
\hline Information and Management & 1 \\
\hline International Journal of Hospitality Management & 1 \\
\hline International Journal of Operations \& Production Management & 4 \\
\hline International Journal of Physical Distribution and Logistics Management & 2 \\
\hline International Journal of Production Economics & 5 \\
\hline International Journal of Production Research & 3 \\
\hline Journal of Operations Management & 13 \\
\hline Journal of Purchasing and Supply Management & 2 \\
\hline Journal of Supply Chain Management & 3 \\
\hline Knowledge and Process Management & 1 \\
\hline Omega-International Journal of Management Science & 4 \\
\hline Production Planning and Control & 1 \\
\hline Supply Chain Management - an International Journal & 5 \\
\hline Transportation Research Part E: Logistics and Transportation Review & 1 \\
\hline
\end{tabular}

Terms that most appeared in each construct were selected and transcribed to an electronic spreadsheet, all the variables used in the definition of the constructs in each article published. In this sequence, a meticulous analysis was made of each variable, finding terms of greatest use and coherence in the formation/definition of the constructs. A total of 639 variables that defined constructs of Supply Chain Management practices were transcribed. The analysis of these variables resulted in the selection of the words or terms most employed in the studies researched in accordance with contexts in which these word or terms were used. Also, the constructs were grouped according to first and second order with similar definitions so that they could be understood and named by means of more general, deeper concepts (Table 2). The constructs analyzed, despite being similar in the construction of their variables, possessed different nomenclatures, which, at first, proves that the area is still quite incipient in the formation of its concepts, thereby making this an exploratory study. 
Table 2: Result of the analysis of the main terms that define SCM concepts

\begin{tabular}{|c|c|c|c|}
\hline $\begin{array}{r}\text { General } \\
\text { concepts }\end{array}$ & $\begin{array}{l}\text { Second-order } \\
\text { Constructs / } \\
\text { Authors }\end{array}$ & First-order constructs/Authors & Words or terms in the definition of the constructs/Authors \\
\hline 离离高 & $\begin{array}{l}\text { Purchasing } \\
\text { Practices [7] } \\
\text { Sourcing Deci- } \\
\text { sions [2] }\end{array}$ & $\begin{array}{l}\text { Supplier Capability [2]; Supplier performance } \\
\text { evaluation [7]; Formalized vendor rating/ranking } \\
\text { procedures [5]; Performance Evaluation [24] } \\
\text { Supplier development support [23]; Supplier evo- } \\
\text { lution system [3]; Supplier evaluation [28]; Sup- } \\
\text { plier Management [41]; }\end{array}$ & $\begin{array}{l}\text { Certification }[3,5,7,24] \text {; Demand }[28] \text {; Design }[7,28,30] \text {; Eva- } \\
\text { luate }[3,6,8,23,24] \text {; Feedback }[6,23,24] ; \text { Formal system [3]; } \\
\text { Improve and performance }[3,4,6] ; \text { Inspection }[28,41] ; \text { Modula- } \\
\text { rization }[7] ; \text { On-time delivery }[28,37] ; \text { Performance }[3,4,5,6 \text {, } \\
15,20,24,31,40] \text {; Quality }[2,5,15,20,28,30,31,41] \text {; Price }[28] \text {; } \\
\text { Reputation [28]; Reliability }[2,5,28] \text {; Schedule [7]; Service }[4,5] \text {; } \\
\text { Technological [5] }\end{array}$ \\
\hline 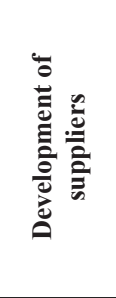 & $\begin{array}{l}\text { Operational } \\
\text { link [5] } \\
\text { Supply chain } \\
\text { Integration [9] }\end{array}$ & $\begin{array}{l}\text { Product/process development Supplier [5]; } \\
\text { Supplier assistance and training [5]; Company's } \\
\text { integration with suppliers [9,33]; Co-operation } \\
\text { [18]; Direct involvement [6]; } \\
\text { Purchasing/supplier involvement [10]; } \\
\text { Supplier development support [23]; Supplier } \\
\text { involvement—product development [20]; Supplier } \\
\text { management [41]; Supply chain practices [30] }\end{array}$ & $\begin{array}{l}\text { Design [7, 9, 10, 15, 18, 19,20,31,33,39, 40]; Develop and pro- } \\
\text { duct [5]; Evaluate or evaluating [23]; Feedback [23]; Information } \\
\text { sharing [15, 26, 30, 39]; JIT [30,37,39]; Problem [7, 23, 39]; } \\
\text { Support or assistance [5, 10, 14, 23, 40]; Technical expertise or } \\
\text { technical support or technical assistance or technical skill [5, 23, 24, } \\
\text { 50]; Tool [5]; Training [6] }\end{array}$ \\
\hline
\end{tabular}


Table 2 (Continuation)

\begin{tabular}{|c|c|c|c|}
\hline 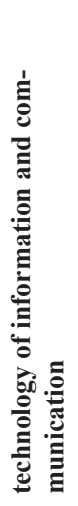 & $\begin{array}{ll}- & \text { Supply chain } \\
& \text { concerns }[30] \\
\text { - } & \text { SC IT Capabilities } \\
& {[40] ;}\end{array}$ & $\begin{array}{l}\text { Coherence and information systems } \\
\text { [30]; IT use for exploration [26, 40]; } \\
\text { Advanced communication methods } \\
\text { (ACM) [23, 51]; E-procurement } \\
\text { technology [44]; Exploitation [26, } \\
\text { 40]; Information technology [15, 20]; } \\
\text { Information sharing [45]; Integrative } \\
\text { information technologies [12]; Internal } \\
\text { integration across the supply chain } \\
\text { [9, 33]; IT use for exploration [26]; } \\
\text { Operational coordination [26]; Strategic } \\
\text { coordination [26], Supply chain } \\
\text { management practices [37]; Traditional } \\
\text { communication methods (TCM) [23], } \\
\text { Leveraging the internet [51] }\end{array}$ & $\begin{array}{l}\text { Communicate [23]; Communicate [23]; EDI [8, 12, 23, 29, 32, 44]; } \\
\text { EDI Capabilities [46]; Extranet [44]; E-mail [44]; Electronic Cata- } \\
\text { logs [44]; Electronic File Transferring [44]; Electronic Market [44]; } \\
\text { Forecasts [45]; Information sharing [15, 26, 30, 39, 51]; Information } \\
\text { systems [12, 20, 30]; Integrate or Integrating or integration [9, 12, } \\
\text { 26, 30, 33, 35, 37, 39]; Integrated or integration [20, 26, 40]; Internet } \\
\text { Auctions [44]; Inventory or raw material and finished good inven- } \\
\text { tories or work-in-process inventories [45, 51]; Long-term strategic } \\
\text { plans [45]; New product [26, 45]; Search internet [44]; Strategic } \\
\text { planning [26]; Technology [15, 20]; Trust [30]; Video Conferencing } \\
\text { [44]; Purchasing material and services [51]; Selling products and ser- } \\
\text { vices [51], material requirements planning (MRP) systems [51], ERP } \\
\text { systems [51], collaborative planning, forecasting, and replenishment } \\
\text { (CPFR) [51], activity-based costing (ABC) accounting methods [51] }\end{array}$ \\
\hline 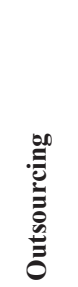 & $\begin{array}{l}\text { Outsourcing decision } \\
\text { factor [36] } \\
\text { Part characteristics [36] } \\
\text { Outsourcing drives [47] }\end{array}$ & $\begin{array}{l}\text { Cost related outsourcing [47]; Flexibility } \\
\text { related outsourcing [47]; Innovativeness } \\
\text { related outsourcing [47]; Motives [36]; } \\
\text { Part characteristics [36]; Quality related } \\
\text { outsourcing [47]; Supplier operating } \\
\text { capabilities [36]; Supplier relationship } \\
\text { strategies [36]; Time related outsourcing } \\
\text { [47]; Supply network structure [51] }\end{array}$ & $\begin{array}{l}\text { Common work [36]; Core competencies-low cost [47]; Cost [36]; } \\
\text { Cycle times [36]; Design [36]; Engineering/design [36]; Focus [36]; } \\
\text { Higher volumes [36, 47]; Innovation [47]; Lead time [36]; Legal } \\
\text { costs [47]; Logistics costs [47]; Low wage countries [36]; New } \\
\text { technology [36]; Outsourced parts [36, 51]; Production plans [36]; } \\
\text { Production processes [36]; Purchasing materials [36]; Quality [36]; } \\
\text { Responsiveness [36, 47]; Specific labor [47]; Technology expertise } \\
\text { [36] }\end{array}$ \\
\hline 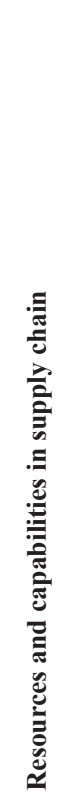 & $\begin{array}{l}\text { Antecedents of Supply } \\
\text { Chain Learning [39] } \\
\text { Applied SCM Process } \\
\text { Knowledge [39] } \\
\text { Environmental Know- } \\
\text { ledge [39] } \\
\text { Knowledge-sharing } \\
\text { routines [48] } \\
\text { Learning [48] } \\
\text { SC Organizational } \\
\text { Capabilities [40] } \\
\text { Supply Chain Learning } \\
\text { [39] } \\
\text { Supply chain compe- } \\
\text { tence [30] }\end{array}$ & $\begin{array}{l}\text { Applied SCPK-customers [39]; Ap- } \\
\text { plied SCPK-suppliers [39]; Behavior } \\
\text { control [48]; Commitment [39]; Com- } \\
\text { munication [39]; Coordination [40]; } \\
\text { Customer involvement [40]; Design } \\
\text { effectiveness [30]; Extent of use of in- } \\
\text { tegrative [39]; Interfirm social enfor- } \\
\text { cement [48]; Joint decision-making } \\
\text { [39]; Knowledge-sharing routines } \\
\text { [48]; Learning encouragement [39]; } \\
\text { Learning from the interfirm rela- } \\
\text { tionship [48]; Learning structure/ } \\
\text { system/process [39]; Mechanism } \\
\text { within supply chain [39]; Operations } \\
\text { and distribution [30]; Output control } \\
\text { [48]; Planning [40]; Quality and ser- } \\
\text { vice [30]; Relationship specific assets } \\
\text { [48]; Shared culture [39]; Supplier } \\
\text { involvement [40]; Trust [39]; Win- } \\
\text { win approach [39] }\end{array}$ & $\begin{array}{l}\text { Customer [39, 40, 48]; Delivery [39, 40]; Design [30, 39, 40]; Dis- } \\
\text { tribution }[40,48] \text {; Forecasts }[30,39,40] \text {; high-quality products [30]; } \\
\text { high-quality services [30]; Innovation [39, 40, 48]; inventory [30]; } \\
\text { key customers [30]; key suppliers [30]; Know-how [40, 48]; low- } \\
\text { pollution [30]; Marketplace }[40,48] \text {; Performance }[30,40,48] \text {; promi- } \\
\text { sed delivery date [30]; Sharing information or Exchange Information } \\
{[39,48] \text {; timely [30] }}\end{array}$ \\
\hline
\end{tabular}

Note: [1] Vickery et al. (1997); [2] Narasimhan and Jayaram (1998); [3] Carr and Pearson (1999); [4] Carr and Smeltzer (1999); [5] De Toni and Nassimbeni (2000); [6] Krause et al. (2000); [7] Narasimhan and Das (2001); [8] Dong et al. (2001); [9] Narasimhan and Kim (2002); [10] Carr an Pearson (2002); [11] Kaynak (2002); [12] Vickery et al. (2003); [13] Kannan and Tan (2004); [14] Tracey et al. (2004); [15] Chen et al.(2004); [16] Lin et al.(2005); [17] Kannan and Tan (2005); [18] Fynes et al. (2005b), [19] Fynes et al. (2005a); [20] Paulraj et al. (2006); [21] Li et al. (2006); [22] Sengupta et al. (2006); [23] Carr and Kaynak (2007); [24] Krause et al. (2007); [25] Yeung (2008); [26] Sanders (2008); [27] Germain et al. (2008); [28] Karim et al. (2008); [29] Robb et al. (2008); [30] Chow et al. (2008); [31] Paulraj et al. (2008); [32] Sharma et al. (2008); [33] Kim (2009); [34] Sodhi and Son (2009); [35] Iyer et al. (2009); [36] Dabhilkar et al. (2009); [37] Hsu et al. (2009); [38] Kim et al. (2009); [39] Sambasivan et al. (2009); [40] McKone-Sweet and Lee (2009); [41] Ou et al. (2010); [42] Flynn et al. (2010); [43] Fantazy et al. (2010); [44] Quesada et al. (2010); [45] Wiengarten et al. (2010); [46] Tan et al. (2010); [47] Kroes et al. (2010); [48] Hernández-Espallardo et al. (2010); [49] Wiengarten et al. (2010); [50], Cao e Zhang (2011); [51] Cook et al. (2011) 


\section{Definitions of the general concepts of SCM prac- tices}

Through theoretical review, analysis of the constructs of the first and second order and main words common to the variables used by the authors researched, it was possible to group the constructs into six general concepts, as presented in the first column of Chart 2: (a) Supplier performance evolution; (b) Development of suppliers; (c) Management of supplier-customer relationships; (d) Information and communication technology; (e) Outsourcing; (f) Resources and capabilities in supply chains. Below, the definitions of such concepts are presented.

a) Supplier performance evolution. This concerns the process of selection and evaluation of performance. The purchasing function is responsible for executing these activities in conjunction with other areas, such as quality and finance. However, each sector has its specific way of making the performance evaluation. In the performance evaluations, quantitative tools, dialogues with suppliers and indepth analysis of performance are used. Reports, quarterly and annual evaluations are expected, as well as recognition of the best supplier performances (Carr \& Kaynak, 2007). In the performance evaluations, capabilities are often measured in terms of cost, quality, reliability and flexibility (Narasimhan \& Jayaram, 1998). In a complementary manner, Narasimhan and Das (2001) state that the evaluation of the suppliers concerns having the ability to modify a product when necessary without excessive cost or time penalties, responsiveness to schedule delivery change, besides the skill to alter the production mix and possess capacity for modularization of suppliers' products.

b) Development of the suppliers. It is understood as ample technical support for the key suppliers, for example, investment in equipment, personnel training, feedback from results, visits to the suppliers' factories, and certification of the suppliers (Carr \& Kaynak, 2007). In turn, Carr and Pearson (2002) named the construct, purchasing/supplier involvement, which indicates the involvement of suppliers in the product and design process, in the support to the suppliers for innovations in the development of new products, involvement of the suppliers in multi-functional groups.

c) Management of the supplier-customer relationships. This concept has a broad definition, which may mean longer term interaction with greater synergy between the suppliers and contractors, involving economic and behavioral questions, for example, confidence and capital investment (Narasimhan \& Das, 2001). Yeng (2008) named this strategic supply management construct, which is a long-term undertaking, planned to create a database of accredited suppliers that will lead to benefits in supply management. Sodhi and Son (2009) present the following practices for definition of joint partnership management between the supplier and contractors: existence of well-defined guidelines and responsibilities with specific partners, participation of suppliers in decision-making processes, existence of a regular communication system, and the system of division of risks and benefits. Paulraj et al. (2006) named the concept of supply integration, which represents critical integration of various key functions of the organization and occur through use of the integration of information (organizational systems and communication from both sides), multifunctional teams, logistical integration, among others. The cited authors complement that the concept involves strategic initiatives, and a long-term relationship with a limited number of suppliers. Nowadays, some authors call the management practices of the supplier-customer relationships in broader constructs of supply chain integration (SCI) (Flynn et al., 2010) and supply chain collaboration (SCC) (Cao \& Zhang, 2011; Wiengarten et al., 2010). The terms collaboration and integration are related and often used interchangeably (Wiengarten et al., 2010).

The SCI concerns strategic collaboration with partners in the supply chain and collaborative management of the processes among the firms and in intraorganizational terms. The definition of the construct includes the importance of strategic collaboration, mutual achievement of strategic objectives, confidence, increase in the duration of contracts and encourages the settlement of conflicts, integration of information, rewards and risks. Such integration involves a variety of activities aimed at administrative tasks of transport and materials. It is to be stressed that the construct, SCI is of the second-order, involving the sub-constructs, customer integration, supplier integration and internal integration (Flynn et al., 2010).

On the other hand, SCC is defined as a partnership process where two or more autonomous firms work together closely to plan and execute supply chain operations toward common goals and mutual benefits. Supply chain collaboration has seven interconnect- 
ing components: information sharing, goal congruence, decision synchronization, incentive alignment, resources sharing, collaborative communication, and joint knowledge creation (Cao \& Zhang, 2011).

\section{d) Information and communication technology.}

These are technologies that facilitate the flow of information among participants and thus facilitate integration of the internal functional processes and integration among the firms (Vickery et al., 2003). They involve traditional technologies, such as, telephone, fax (Carr \& Kaynak, 2007) and more recent technology like EDI (Carr \& Kaynak, 2007; Iyer et al., 2009; Vickery et al., 2003), ERP (Carr \& Kaynak, 2007), ecommerce, application softwares based on the Internet (Iyer et al., 2009) and JIT, flexible manufacturing systems (Robb et al., 2008). Mckone-Sweet and Lee (2009) and Sanders (2008) present the concept, exploitation and exploration for the employment of capabilities in Information Technology (IT). Exploitation means the use of IT to improve operational efficiency, for example, via information exchange, processing of production orders and inventory control. On the other hand, the term exploration concerns the use of IT to learn about the environment and discover new ways of creating value in the supply chain, such as: becoming acquainted with and making the markets uniform in order to seek new potential sources, and aid the process of collaboration with suppliers and clients.

e) Outsourcing. In the sample researched, two studies were found that analyze the relation between outsourcing and performance: the studies of Dabhilkar et al. (2009) and Kroes and Ghosh (2010). Both studies define outsourcing based on the theory of make-or-buy decisions, employing the theories of the Transaction Cost Economics and ResourceBased View. Kroes and Ghosh (2010) add two more: the Agency Theory and the Knowledge-Based Theory in the context of the supply chain. In summarized form, according to Dabhilkar et al. (2009), and Kroes and Ghosh (2010), the Theory of Agency means the employment of outsourcing as a decision to delegate responsibility to another organization (agent) that can create a product or service more effectively than the main firm (Kroes \& Ghosh, 2010). Regarding the Economics Theory of Transaction Costs, the adoption of outsourcing results in reduction in firm size, that leads to an overall reduction in transaction costs. Such a theory specifies the economic conditions that an organization should manage when it produces a product/service internally and externally (Dabhilkar et al., 2009; Kroes \& Ghosh, 2010). Williamson (1975) states that the decrease in transaction costs (or scope of the firm) occurs by means of uncertainties, frequency and specificities of the assets. The vertical integration can be explained by the different types or attributes of the transactions that lead to different forms of governance. The more complex and uncertain the attributes, the greater the possibility of vertical integration of the firm. In the ambit of the theory of Resource-Based View, the key resources and core business of the organization are evaluated, which must be conducted internally as a counterpart to other activities, for which outsourcing should be employed (Dabhilkar et al., 2009; Kroes \& Ghosh, 2010). Finally, the study of outsourcing employing the theory based on knowledge refers to how much knowledge (internal or external) generates competitive advantage for the purchasing firm (contractor) (Kroes \& Ghosh, 2010).

\section{f) Resources and capabilities in the supply chain.}

This construct is employed in the articles researched involving three main sub-concepts: resources, learning, knowledge and capabilities.

Learning in the supply chain, according to Hernández-Espallardo et al. (2010), represents the knowledge and the capacity to create by means of learning originating from the supply chain' relationship. They are key resources that add value to the processes or products, strategic significance and competitive advantage. The outcome of the knowledge gathered regarding the client's needs is generally due to the greater proximity to the final market, offering a more precise definition of the current demand and its dynamic, facilitating the suppliers' decison-making in the market. The competitiveness of the chain can evolve by means of the division of knowledge, presenting improvements in terms of service cost, cycle time, co-ordination of activities, and, consequently, competitive advantage. Hernández-Espallardo et al. (2010) use two main concepts: (a) output control, referring to the evaluation that the client makes of the performance/results of the suppliers or manufacturers in terms of the achievement expected for certain outcomes and progress in the achievement of objectives, and; (b) behavior control, which concerns the exchange of opinions between clients and suppliers or manufacturers with the aim of improving their activities. Sambasivan et al. (2009) use the same thought when defining learning in the supply chain. According to these authors, the learning originates from the stimulus given 
to the members of the supply chain to share new knowledge and ideas, as well as from the existence of structure, processes and systems for the exchange of new ideas. On the other hand, Mckone-Sweet and Lee (2009) agree with the traditional perspective of the resources and capabilities (Amit \& Schoemaker, 1993). These authors defined that "resources are defined as productive factors that a firm uses to achieve its business objectives, capabilities refer to a firm's ability to deploy these resources to affect a desired end" (McKone-Sweet \& Lee, 2009, p.4). The conceptual framework developed by Mckone-Sweet and Lee (2009) propose six dimensions of capabilities related to the supply chain strategy concept, in which four dimensions refer to concept of organizational capabilities (coordination, planning, supplier involvement and customer involvement) and two dimensions refer to information technology capabilities (IT for exploitation and an IT for exploration).

When dealing with knowledge applied to the supply chain, Hernández-Espallardo et al. (2010) define it as the transfer and internalization of it among firms. It means the division of the knowledge related to routines, so as to define regular patterns of business interaction, allowing the transfer, rearrangement or creation of specialized knowledge. Sambasivan (2009) introduced the concept of knowledge of the environment, which concerns firms identifying risks and uncertainties in the external environment. Such authors argue that the uncertainties have been recognized as one of the root causes of the difficulties in co-ordinating efficiency in the supply chain. Although there is an effort to improve the demand forecast, there are challenges in the competitive environment that affect the performance of forecasts, such as: proliferation of products, short-life products and global expansion of markets and suppliers.

Finally, the concept of organizational capabilities, employed by Mckone-Sweet and Lee (2009), concerning the capabilities the organization possesses for co-ordination and planning in the supply chain through the involvement of suppliers and clients . This concept can also be based on the term, competence. Chow et al. (2008) adopt the supply chain competence construct that refers to the capacity of the supplier to respond to market uncertainties and has skills for operations in the supply chain. Such skills include sales forecasting, inventory planning, supply chain speed and data accuracy.

The six general constructs are illustrated in Figure 1. Next, discussions are presented regarding the variables (or terms) most used and of greatest coherence for definition of the six constructs, as well as pointing out emerging theories in their formations.

Figure 1: SCM practices from 1998 to 2010: general concepts and some second-order constructs

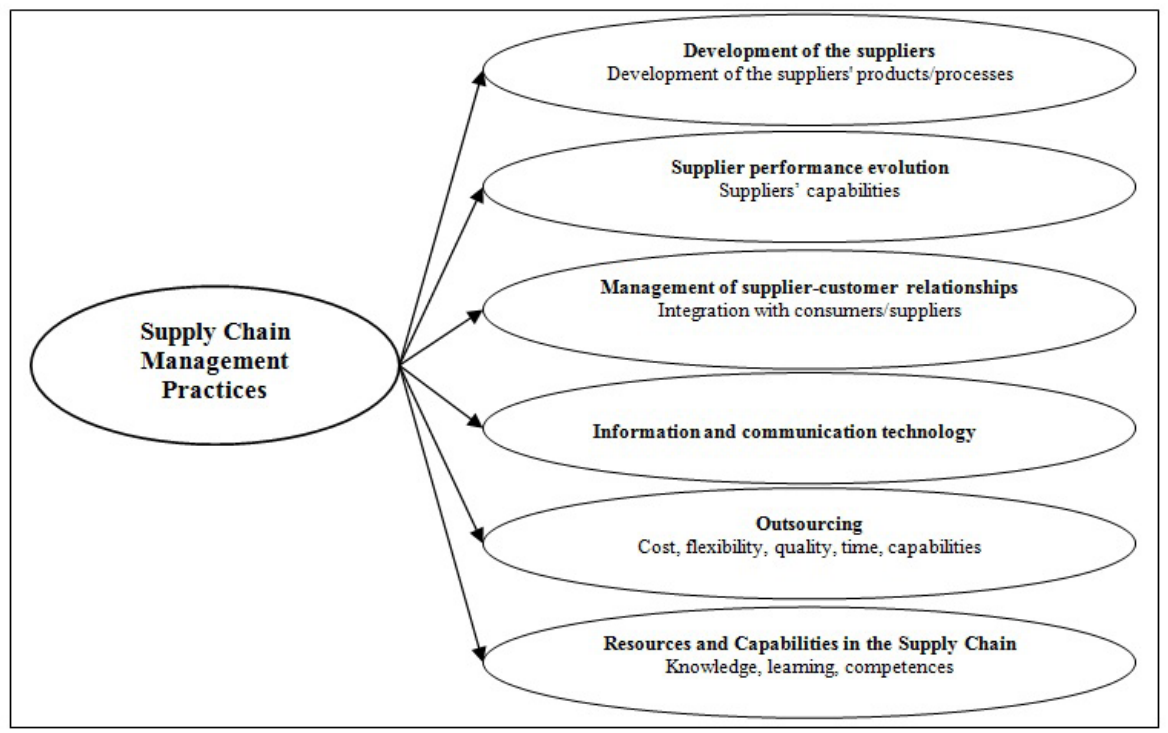




\section{Discussions of the results and perspectives for the concepts of SCM practices}

a.) Supplier performance evolution The term, quality was the most frequently used by the authors in the definition of this concept. Although this term has a broad range of definitions, some researched studies (por exemplo, Chow et al., 2008; De Toni \& Nassimbeni, 2000; Paulraj et al., 2006; Paulraj et al., 2008) do not conceive of quality in a specific manner. Others, like Karim et al. (2008), conceive of its definition using quite traditional approaches, for example, quality of the product and reliability of the technical specifications.

Besides the criterion, quality, it is possible to identify that the evaluation of suppliers occurs via other variables, according to the employment of words in common in the definition of this concept (reliability, certifications, distribution, among others) (Table 2).

Kim et al. (2010) developed a framework for evaluation of the suppliers in the chain based on the European Foundation for Quality Management. Among the authors' arguments for the framework for evaluation of the suppliers is the measurement of intangible results. Such authors argue that the intangible results are key drivers of innovation and core values in the new economy. Besides this, the authors cite that the evaluation criteria must consider the specific nature of each supply chain: the mutuality, the dynamic relations and joint effort for solution of problems. They also consider that the key points of evaluation of suppliers are leadership, commitment, co-ordination, confidence, communication, techniques for conflict settlement, and capabilities. In Table 2, it can be noted that these terms are not presented in the variables of the studies researched. The variables that measure this concept are aimed at traditional variables and do not denote a partnership relationship in the supply chain. Future studies could include the terms and concepts approached by Kim et al. (2010) in order to evaluate a long-term relationship between contractors and suppliers. This result shows how quality occupies an important role in the evaluation of supplier performance.

b) Development of suppliers: In this construct, design was the most used variable in the works researched, meaning the involvement of suppliers in the product development process. They also mentioned support, technical assistance and just-in-time (JIT) as terms related with development of the supplier base. In Table 2, it is possible to observe the variables most used by the researchers to measure this construct.

This construct is mostly related to Supply Chain Management practices. Basically, it involves cooperation, training and support in developing products, processes, and purchasing and delivery systems, with the suppliers. Thus, these practices vary from the development of products to the collaborative practices and co-ordination of the logistics and the supply chain.

c) Management of the supplier-customer relationships: Table 2 highlights the words of greatest use in the definition, among which there are key suppliers and communication. Moreover, in the definition of this concept, one can observe words used more than once by different authors. The word, feedback can be used to represent various meanings. For example, it is used in the supply (or exchange of opinions) of results of performance on the product's quality process or product development between suppliers and contractors (Karim et al., 2008). Also, it can be used to represent an exchange of information (opinions) about performance in general, within the concept of inter-organizational communication (Paulraj et al., 2008). The same occurs with the practice of multifunctional groups that can be employed as much to give support to strategic objectives aimed at innovation or total quality management (Vickery et al., 2003) as to integrate communication among the different hierarchical levels and work units (functions and processes) (Germain et al., 2008).

The term, information sharing is also used for information exchange in the process of new product development, to obtain knowledge about stock levels, delivery periods and production schedules (Hsu et al., 2009).

Furthermore, in the definition of this construct, it is possible to include variables of the constructs, strategic purchasing, communication and supplier relationship. Although some authors have employed these constructs separately (for example, Carr \& Smeltzer, 1999; Fantazy et al., 2010), the understanding of such concepts involve very similar subjects. For instance, in the definition of strategic purchasing, it is well established that the organization includes guidelines for the purchasing function in the strategic planning, as well as long term planning for material and service purchases, besides the fact that the purchasing function possesses specific strategic planning (Carr \& Smeltzer, 1999; Fantazy et al., 2010; Paulraj et al., 2006). 
In the supplier relationship, there appear variables of the integration of systems and production planning, adaptations in the production process, work in conjunction focusing on cost reduction and involvement in the product development process (Dabhilkar et al., 2009), besides product development with suppliers and integration of the production planning decisions. Robb et al. (2008) include frequent communication with suppliers and a strong relationship with most of them. Karim (2008) employs the inspection of products, integration of information to improve the quality of the product, awareness of the quality of the products supplied and use of feedback from suppliers to develop new products. Fantazy et al. (2010), in turn, emphasize developing the relationship with a reduced number of suppliers, or the main ones, to improve the quality of the product and develop partnership programs. At this point, it is perceived that the use of the variable, "involvement of the suppliers in the strategic planning" is also included in the concept of strategic purchasing.

In turn, the concept of communication involves integration of the main suppliers for frequent exchange of information that is accurate and reliable. It also involves frequent face-to-face communication with the suppliers, besides engaging them in the strategic planning process (Carr \& Smeltzer, 1999; Fantazy et al., 2010). The use of the variable, information exchange or information integration is also employed in the concept, relationship with suppliers.

Furthermore, in the construct, communication and supplier relationships, similar variables (or the same main words and terms) of the construct, supply chain integration (SCI), are frequently employed. Flynn et al. (2010) report that the critical elements of the SCI have a broad focus, able to involve integration of flows of materials or parts of products, or even the flow of information, resources and money. In defining the SCI, such authors consider the manufacturers (involving the internal integration), extending to the integration of suppliers and consumers.

In bearing similarities in the definitions and employment of the variables, this study suggests a general definition of this construct because of involving subconstructs of the constructs, strategic purchasing, supplier relationship, communication and supply chain integration. Thus, the construct would also involve the relations with clients, besides suppliers, as presented by Flynn et al. (2010).

d) Information and communication technology: Some recent studies analyze the effects of technolo- gies involved in this construct on the performance of the firm, based on the theories of Transaction Cost and the Resource-Based View. For example, Tan et al. (2010) validated the construct EDI capabilities and studied its alignment with objectives of information integration and business performance. Thus, future studies could employ these theories in other emerging technologies, such as e-commerce, e-sourcing, e-procurement and electronic auctions.

Also, as it deals with emerging technologies, more studies are necessary for validation of specific concepts of practices in the supply chain functions and information technologies in order to analyze their effects on the efficiency of the supply chain processes. Among the studies researched, there was only Quesada et al. (2010) that validated IT constructs, aimed at e-procurement, procurement practices and purchasing performance.

e) Outsourcing: In this concept, the use of the following are recent: theories of Transaction Cost Economics and the Resource-Based View (RBV), Agency Theory, Networks and Knowledge-Based View. The perfection of the construct, outsourcing, in these approaches, can lead to contributions for the operations area. In the studies evaluated (Table2), few terms in common are employed, although the studies involve similar theoretical fundamentals. For example, in evaluating aspects of outsourcing in the RBV, Dabhilkar et al. (2009) use variables that measure the capabilities of the suppliers when the outsourcing is aimed at large volumes, design/engineering, operations in countries with low salaries and little purchasing of materials. In turn, Kroes and Ghosh (2010) verified access to specific labor and/or technological expertise, the permanence of resources to focus on core competencies and acquisition of new technologies.

In addition, researches evaluating strategic alignments and performance, on the basis of these four theories, are still limited, requiring greater standardization of these concepts in the context of the supply chain.

f) Resources and capabilities in the supply chain: According to the articles analyzed, the theory of the Resource-Based View (RBV) in the supply chain is a field of knowledge quite recent in the area of SCM, and is still little explored. In the review of the articles, 19 variables were found, in which only 9 words were commonly used by the authors (Table 2). This reveals that the definitions of the concepts and their 
use in this line are still not established, that is, are undergoing formation and present an incipient character. For a deeper fundamental understanding, it is suggested that future studies involve the three sub-concepts found in the literature: Learning, Knowledge and Capabilities.

Additionally, a clearer definition of the difference between supply chain practices and capabilities would be welcome. Wu et al. (2010) defined that operational practices are fairly standardized activities, programs, or procedures that are developed to address the attainment of specific operational goals. On the other hand, operation capabilities are "firm-specific sets of skills, processes, and routines, developed within the operations management system, that are regularly used in solving its problems through configuring its operational resources" (Wu et al. 2010, p. 726). Therefore, the capabilities term has presented some subdivisions, such as the concepts of operational capabilities and competitive capabilities. Kim (2006; 2009) advocated that non-imitable internal resources and capabilities generate superior rents and provide intensive competitive capabilities. Kim (2009) developed four competitive capabilities constructs for supply chain strategy: cost leadership, customer service, marketing technology and differentiation. Although there are studies focused on the capabilities concept, definitions from of the operations and supply chain field are still scarce.

\section{Conclusions and limitations of the study}

In the analysis of the constructs and sub-constructs of the SCM practices, similarity is noted in the employment of their variables and common use of words (or terms) in the definition of the concepts. However, the constructs possess different nomenclatures. Therefore, confusion is present in the studies analyzed. This article proposed to conduct a meticulous analysis in order to identify which practices in the supply chain were most employed in the area, by the identification of the words most employed and greatest coherence in the definition of concepts. From analysis of the articles, constructs of the first and second order were also found. Such constructs and terms were regrouped into six concepts of supply chain practices defined in a broader, deeper form, according to the grouping of the constructs and systematization of the terms develops in Table 2.

The naming of six broader constructs (supplier performance evolution, supplier development, man- agement of relations: supplier-customer, information and communication technology, outsourcing and resources and capabilities) provided a greater understanding and a more appropriate positioning of the concepts.

The study sought to contribute to greater discernment of the concepts, making a critical and reflective understanding of the practices in the area by conducting a deeper evaluation of the variables and terminologies employed in the articles studied. In the subsections of the discussions it was observed that the authors used the same terms in different contexts, what is relatively common in the area of operations management, in which there is multidisciplinarity of knowledge, skill and functions. The article also sought to contribute by pointing out the future prospects for formation of the concepts, showing how such constructs are being modified and improved by the introduction of theories, such as the theory of Transaction Cost, the Resource-Based View, Agency Theory, and Knowledge-Based Theory.

On the other hand, the study also presents some limitations. The first concerns the exploratory method of data analysis, which consisted in the meticulous evaluation of the terms and variables employed in the constructs, without the use of more technologically advanced methods and resources, as the terminological confusion was present at the theoretical base. Therefore, the Zipf's bibliometric law (for example, Bence \& Oppenheim, 2004) was not totally used in this study due to complexity of the concepts.

Also, the six more general constructs of Supply Chain Management practices named in this work are not exhaustive for all the practices in the area, as two databases were used as criterion for selection of the articles (Scopus and Web of Science), and the Boolean expression, "Supply Chain Managemen and performance" was entered in the search box. In addition, the six constructs were not tested in this article by means of empirical research in the true sense of the word, although the sample of articles selected are all empirical studies.

\section{References}

Amit, R., \& Schoemaker, P. J. H. (1993). Strategic assets and organizational rent. Strategic Management Journal, 14(1), 33-46.

Arzu Akyuz, G., \& Erman Erkan, T. (2010). Supply chain performance measurement: A literature review. International Journal of Production Research, 48(17), 5137-5155. 
Bence, V., \& Oppenheim, C. (2004). Does Bradford-Zipf apply to business and management journals in the 2001 Research Assessment Exercise? Journal of Information Science, 30(5), 469-474.

Bozarth, C. C., Warsing, D. P., Flynn, B. B., \& Flynn, E. J. (2009). The impact of supply chain complexity on manufacturing plant performance. Journal of Operations Management, 27(1), 78-93.

Cao, M., \& Zhang, Q. (2011). Supply chain collaboration: Impact on collaborative advantage and firm performance. Journal of Operations Management, 29(3), 163-180.

Carr, A. S., \& Kaynak, H. (2007). Communication methods, information sharing, supplier development and performance: an empirical study of their relationships. International Journal of Operations \& Production Management, 27(4), 346-370.

Carr, A. S., \& Pearson, J. N. (1999). Strategically managed buyersupplier relationships and performance outcomes. Journal of Operations Management, 17(5), 497-519.

Carr, A. S., \& Pearson, J. N. (2002). The impact of purchasing and supplier involvement on strategic purchasing and its impact on firm's performance. International Journal of Operations $\mathcal{E}$ Production Management, 22(9), 1032-1053.

Carr, A. S., \& Smeltzer, L. R. (1999). The relationship of strategic purchasing to supply chain management. European Journal of Purchasing \& Supply Management, 5, 43-51.

Chen, I. J., Paulraja, A., \& Lado, A. A. (2004). Strategic purchasing, supply management, and firm performance. Journal of Operations Management, 22(5), 505-523.

Chow, W. S., Madu, C. N., Kuei, C., Lu, M. H., Lin, C., \& Tseng, H. (2008). Supply chain management in the US and Taiwan: An empirical study. Omega-International Journal of Management Science, 36(5), 665-679.

Cook, L. S., Heiser, D. R., \& Sengupta, K. (2011). The moderating effect of supply chain role on the relationship between supply chain practices and performance: An empirical analysis. International Journal of Physical Distribution and Logistics Management, 41(2), 104-134.

Dabhilkar, M., Bengtsson, L., von Haartman, R., \& Ahlström, P. (2009). Supplier selection or collaboration? Determining factors of performance improvement when outsourcing manufacturing. Journal of Purchasing and Supply Management, 15(3), 143-153.

De Toni, A., \& Nassimbeni, G. (2000). Just-in-time purchasing: an empirical study of operational practices, supplier development and performance. Omega-International Journal of Management Science, 28(6), 631-651.

Dong, Y., Carter, C. R., \& Dresner, M. E. (2001). JIT purchasing and performance: an exploratory analysis of buyer and supplier perspectives. Journal of Operations Management, 19(4), 471-483.

Fantazy, K. A., Kumar, V., \& Kumar, U. (2010). Supply management practices and performance in the Canadian hospitality industry. International Journal of Hospitality Management, 29(4), 685-693.
Flynn, B. B., Huo, B., \& Zhao, X. (2010). The impact of supply chain integration on performance: A contingency and configuration approach. Journal of Operations Management, 28(1), 58-71.

Frohlich, M. T., \& Westbrook, R. (2001). Arcs of integration: an international study of supply chain strategies. Journal of $\mathrm{Op}$ erations Management, 19(2), 185-200.

Fynes, B., Voss, A. C., \& Búrca, S. (2005a). The Impact Of Supply chain relationship dynamics on manufacturing performance. International Journal of Operations \& Production Management, 25(1), 6-19.

Fynes, B., Voss, A. C., \& Búrca, S. (2005b). The impact of supply chain relationship quality on quality performance. International Journal Of Production Economics, 96, 339-354.

Germain, R., Claycomb, C., \& Droge, C. (2008). Supply chain variability, organizational structure, and performance: The moderating effect of demand unpredictability. Journal of $\mathrm{Op}$ erations Management, 26(5), 557-570.

Hair Júnior, J. F., Anderson, R. E., Tatham, R. L., \& Black, W. C. (2005). Multivariate Data Analysis (6 ed.). Upper Saddle River: Prentice Hall.

Hernández-Espallardo, M., Rodríguez-Orejuela, A., \& SánchezPérez, M. (2010). Inter-organizational governance, learning and performance in supply chains. Supply Chain Management: An International Journal, 15(2), 101-114.

Hsu, C. C., Tan, K. C., Kannan, V. R., \& Keong Leong, G. (2009). Supply chain management practices as a mediator of the relationship between operations capability and firm performance. International Journal of Production Research, 47(3), 835-855.

Iyer, K. N. S., Germain, R., \& Claycomb, C. (2009). B2B e-commerce supply chain integration and performance: A contingency fit perspective on the role of environment. Information and Management, 46(6), 313-322.

Kannan, V. R., \& Tan, K. C. (2004). Supplier alliances: Differences in attitudes to supplier and quality management of adopters and non-adopters. Supply Chain Management, 9(4), 279-286.

Kannan, V. R., \& Tan, K. C. (2005). Just in time, total quality management, and supply chain management: understanding their linkages and impact on business performance. OmegaInternational Journal of Management Science, 33, 153-162.

Karim, M. A., Smith, A. J. R., Halgamuge, S. K., \& Islam, M. M. (2008). A comparative study of manufacturing practices and performance variables. International Journal Of Production Economics, 112(2), 841-859.

Kaynak, H. (2002). The relationship between just-in-time purchasing techniques and firm performance. IEEE Transactions on Engineering Management, 49(3), 205-217.

Kim, D.-Y., Kumar, V., \& Kumar, U. (2010). Performance assessment framework for supply chain partnership. Supply Chain Management: An International Journal, 15(3), 187-195.

Kim, J., Hwang, Y., \& Park, K. (2009). An assessment of the recycling potential of materials basedon environmental and economic factors; case study in South Korea. Journal of Cleaner Production, 17(14), 1264-1271. 
Kim, S. W. (2006). Effects of supply chain management practices, integration and competition capability on performance. Supply Chain Management: An International Journal, 11(3), 241-248.

Kim, S. W. (2009). An investigation on the direct and indirect effect of supply chain integration on firm performance. International Journal Of Production Economics, 119(2), 328-346.

Krause, D. R., Handfield, R. B., \& Tyler, B. B. (2007). The relationships between supplier development, commitment, social capital accumulation and performance improvement. Journal of Operations Management, 25(2), 528-545.

Krause, D. R., Scannell, T. V., \& Calantone, R. J. (2000). A structural analysis of the effectiveness of buying firms' strategies to improve supplier performance. Decision Sciences, 31(1), 33-55.

Kroes, J. R., \& Ghosh, S. (2010). Outsourcing congruence with competitive priorities: Impact on supply chain and firm performance. Journal of Operations Management, 28(2), 124-143.

Li, S., Ragu-Nathanb, B., Ragu-Nathanb, T. S., \& Rao, S. S. (2006). The impact of supply chain management practices on competitive advantage and organizational performance. OmegaInternational Journal of Management Science, 34(2), 107-124.

Lin, C., Chow, W. S., Madu, C. N., Kuei, C., \& Yu, P. P. (2005). A structural equation model of supplychain quality management and organizational performance. International Journal Production Economics, 96(3), 355-365.

Matitz, Q. R. S., \& Vizeu, F. (2010). Construção e uso de conceitos em estudos organizacionais: por uma perspectiva social e histórica. Rio de Janeiro/RJ - Brasil: Associação Nacional de Pós-Graduação e Pesquisa em Administração - ANPAD.

McKone-Sweet, K., \& Lee, Y. T. (2009). Development and analysis of a supply chain strategy taxonomy. Journal of Supply Chain Management, 45(3), 3-24.

Narasimhan, R., \& Das, A. (2001). The impact of purchasing integration and practices on manufacturing performance. Journal of Operations Management, 19(5), 593-609.

Narasimhan, R., \& Jayaram, J. (1998). Causal linkages in supply chain management: An exploratory study of North American manufacturing firms. Decision Sciences, 29(579-605).

Narasimhan, R., \& Kim, S. W. (2002). Effect of supply chain integration on the relationship between diversification and performance: evidence from Japanese and Korean firms. Journal of Operations Management, 20(3), 303-323.

Ou, C. S., Liu, F. C., Hung, Y. C., \& Yen, D. C. (2010). A structural model of supply chain management on firm performance. International Journal of Operations and Production Management, 30(5), 526-545.

Paulraj, A., Chen, I. J., \& Flynn, J. (2006). Levels of strategic purchasing: Impact on supply integration and performance. Journal of Purchasing \& Supply Management, 12(3), 107-122.

Paulraj, A., Lado, A. A., \& Chen, I. J. (2008). Inter-organizational communication as a relational competency: Antecedents and performance outcomes in collaborative buyer-supplier relationships. Journal of Operations Management, 26(1), 45-64.

Quesada, G., González, M. E., Mueller, J., \& Mueller, R. (2010). Impact of e-procurement on procurement practices and per- formance. Benchmarking, 17(4), 516-538.

Robb, D. J., Xie, B., \& Arthanari, T. (2008). Supply chain and operations practice and performance in Chinese furniture manufacturing. International Journal Of Production Economics, 11(2), 683-699.

Sambasivan, M., Loke, S. P., \& Abidin-Mohamed, Z. (2009). Impact of knowledge management in supply chain management: A study in Malaysian manufacturing companies. Knowledge and Process Management, 16(3), 111-123.

Sanders, N. R. (2008). Pattern of information technology use: The impact on buyer-suppler coordination and performance. Journal of Operations Management, 26(3), 349-367.

Sengupta, K., Heiser, D. R., \& Cook, L. S. (2006). Manufacturing and service supply chain performance: a comparative analysis. Journal of Supply Chain Management, 42(4), 4-15.

Sharma, M. K., Bhagwat, R., \& Dangayach, G. S. (2008). Performance measurement of information systems in small and medium sized enterprises: A strategic perspective. Production Planning and Control, 19(1), 12-24.

Sodhi, M. S., \& Son, B. G. (2009). Supply-chain partnership performance. Transportation Research Part E: Logistics and Transportation Review, 45(6), 937-945.

Tan, K. C., Kannan, V. R., Hsu, C. C., \& Leong, G. K. (2010). Supply chain information and relational alignments: Mediators of EDI on firm performance. International Journal of Physical Distribution and Logistics Management, 40(5), 377-394.

Tracey, M., Lim, J. S., \& Vonderembse, M. A. (2004). The impact of supply-chain management capabilities on business performance. Supply Chain Management - an International Journal, 10(3-4), 179-191.

Vanpoucke, E., Boyer, K. K., \& Vereecke, A. (2009). Supply chain information flow strategies: an empirical taxonomy. International Journal of Operations \& Production Management, 29(12), 1213-1241.

Vickery, S. K., Droge, C., \& Markland, R. E. (1997). Dimensions of manufacturing: strength in the furniture industry. Journal of Operations Management, 15(4), 317-330.

Vickery, S. K., Jayaram, J., Droge, C., \& Calantone, R. (2003). The effects of an integrative supply chain strategy on customer service and financial performance: an analysis of direct versus indirect relationships. Journal of Operations Management, 21(5), 523-539.

Wiengarten, F., Humphreys, P., Cao, G., Fynes, B., \& McKittrick, A. (2010). Collaborative supply chain practices and performance: Exploring the key role of information quality. Supply Chain Management, 15(6), 463-473.

WILLIAMSON, O. E. (1975). Markets and hierarchies: analysis and antitrust implications. New York: Free Press.

Wu, S. J., Melnyk, S. A., \& Flynn, B. B. (2010). Operational capabilities: the secret ingredient. Decision Sciences, 41(4), 721-754.

Yeung, A. C. L. (2008). Strategic supply management, quality initiatives, and organizational performance. Journal of Operations Management, 26(4), 490-502. 


\section{AUTHOR'S BIOGRAPHY}

Eliciane Maria da Silva is Assistant Professor in Methodist University of Piracicaba. She holds a PhD degree in Production Engineering at the Engineering School of São Carlos (EESC), University of São Paulo (USP). Her areas of interest are operations strategy, supply chain management, best practices and performance measurement.

Mario Sacomano Neto is Assistant Professor in Methodist University of Piracicaba. He holds a PhD degree in Production Engineering at the Universidade Federal de São Carlos (UFSCAR) and was visiting scholar at the University of Chicago (2001). He holds a Master degree in Production Engineering at the Engineering School of São Carlos (EESC), University of São Paulo (USP) and is graduated in Administration.

Sílvio Roberto Ignácio Pires is graduated and has a master and doctoral degree in Production Engineering and more than twenty five years of professional experience as manager, consulting and professor of operations and supply chain management in Brazil, Switzerland, Spain, and France. Alongside he has been working for companies as Volkswagen, International Paper, SAP, Embraer and Vallourec-Mannesmann. 